\title{
MODIFIKASI GENERATOR LISTRIK (GENSET) MENGGUNAKAN BAHAN BAKAR BIOGAS UNTUK PENERANGAN LAMPU JALAN
}

\author{
Oleh: \\ Pungut *) dan Dominggos**)
}

\begin{abstract}
Abstrak
Biogas sebagai sumber energi alternatif yang ramah lingkungan sangat sayang jika tidak dimanfaatkan. Dengan melakukan modifikasi mesin bensin atau diesel ternyata biogas dapat dimanfaatkan sebagai pengganti bahan bakar bensin dan solar. Mesin ini selanjutnya dipakai untuk memutar generator listrik. Perubahan biogas menjadi energi listrik dilakukan dengan memasukan gas dalam tabung penampungan kemudian masuk ke konversion kit yang berfungsi menurunkan tekanan gas dari tabung sesuai dengan tekanan operasional mesin dan mengatur debit gas yang bercampur dengan udara didalam mixer, dari mixer bahan bakar bersama dengan udara masuk kedalam mesin dan terjadilah pembakaran yang akan menghasilkan daya untuk mengerakan generator yang menghasilkan energi listrik.
\end{abstract}

Kata kunci : Biogas, generator, mixer

\section{PENDAHULUAN}

\section{A. Biogas}

Biogas adalah gas yang mudah terbakar (flammable gas) yang diperoleh dari penguraian senyawa-senyawa organik dalam biomassa sebagai akibat aktivitas mikroorganisme (fermentasi) pada kondisi tanpa udara (anaerobic). Kandungan utama biogas adalah gas metana $\left(\mathrm{CH}_{4}\right)$ dan karbon dioksida (CO2). Sebagian kecil adalah gas hidrogen sulfida $\left(\mathrm{H}_{2} \mathrm{~S}\right)$, nitrogen (NA hidrogen $\left(\mathrm{H}_{2}\right)$ dan oksigen (02). Kehadiran gas metana yang besar ini membuat biogas mudah terbakar dan dapat dipakai sebagai sumber energi untuk memasak, penerangan, bahkan pada skala besar dapat menghasilkan energi listrik.

Biogas ini juga menghasilkan produk samping berupa lumpur organik yang dapat diolah menjadi pupuk kompos. Kualitas pupuk kompos yang dihasilkan tergantung pada bahan baku yang digunakan. Pengolahan lanjutan limbah biogas menjadi kompos bukanlah hal yang sulit untuk dilakukan. Pengolahan dilakukan dengan caramemisahkan cairan (bisa digunakan sebagai pupuk cair) dengan padatan melalui proses penyaringan. Kemudian padatannya dikeringkan dan ditambahkan bahan-bahan lain untuk mencapai komposisi senyawa kompos yang diinginkan seperti kandungan nitrogen $(\mathrm{N})$, phosfor $(\mathrm{P})$, kalium $(\mathrm{K})$, magnesium (Mg), kalsium (Ca), dan mineral-mineral lainnya. Bahkan unsur- unsur tertentu seperti protein, selulosa, lignin dan lain-lain tidak bisa digantikan oleh pupuk kimia.

Adapun komposisi gas yang terdapat di dalam unit degestion biogas dapat dilihat pada tabel 1.

Tabel 1. Komposisi gas pada degestion biogas

\begin{tabular}{lcc}
\hline \multicolumn{1}{c}{ Penjelasan } & Rumus & Persentase \\
\hline Metana & $\mathrm{CH}_{4}$ & $55-65 \%$ \\
Karbondioksida & $\mathrm{CO}_{2}$ & $36-45 \%$ \\
Nitrogen & $\mathrm{N}_{2}$ & $0-3 \%$ \\
Hidrogen & $\mathrm{H}_{2}$ & $0-1 \%$ \\
Oksigen & $\mathrm{O}_{2}$ & $0-1 \%$ \\
Hidrogen Sulfida & $\mathrm{H}_{2} \mathrm{~S}$ & $0-1 \%$ \\
\hline
\end{tabular}

Biogas memberikan subtitusi atau penganti dari bahan bakar fosil untuk penerangan dan memasak. Gas methana (044) yang dihasilkan secara alami oleh kotoran yang menumpuk merupakan gas penyumbang terbesar pada efek rumah kaca, bahkan lebih besar dibandingkan dengan gas karbon dioksida (CO2). Pembakaran methana pada biogas mengubahnya menjadi $\mathrm{CO}_{2}$ sehingga mengurangi jumlah methana di udara. Dengan lestarinya hutan, maka gas $\mathrm{CO}_{2}$ yang ada di udara akan diserap oleh hutan yang menghasilkan oksigen yang melawan efek rumah kaca.

*) Dosen Teknik Lingkungan

**) Mahasiswa Teknik Lingkungan

Universitas PGRI Adi Buana Surabaya 


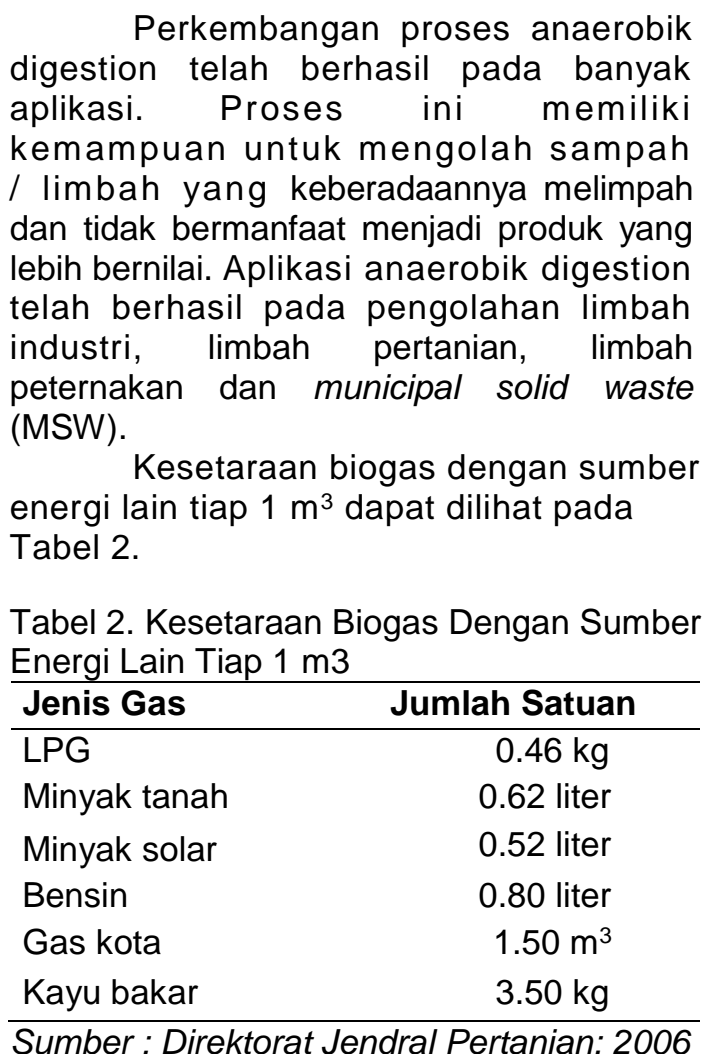

\section{B. Proses Anaerobik dalam Biogas}

Proses pengolahan limbah secara anaerobik merupakan metode yang efektif untuk mengolah berbagai macam limbah organik. Pengolahan ini dimediasi oleh mikroorganisme anaerobic dan mikroorganisme fakultatif yang tidak membutuhkan oksigen yang kemudian mengubah zat-zat organik manjadi produk akhir seperti karbon dioksida (CO2) dan metana $\left(\mathrm{CH}_{4}\right)$. Keuntungan utama pengolahan limbah secara anaerobik dibanding dengan pengolahan secara aerobik adalah sebagai berikut :

1. Menghasilkan biomassa yang relatif lebih sedikit.

2. Mempunyai nilai ekonomis karena menghasilkan gas metana yang bisa digunakan untuk bahan bakar

3. Mampu mengolah bahan organik yang tinggi karena tidak membutuhkan oksigen yang lebih banyak.

Biogas terjadi akibat reaksi anaerobik bahan organik. Menurut Larry Benefield dan Clifford W. Randal reaksi fermentasi pembentukan biogas adalah sebagai berikut :

Asam Asetat :

$\mathrm{CH}_{3} \mathrm{COOH}->\mathrm{CH}_{4}+\mathrm{CO} 2$

Asam Propionat :

1. $\mathrm{CH}_{3} \mathrm{CH}_{2} \mathrm{COOH}+0,5 \mathrm{H}_{2} \mathrm{O} \longrightarrow \mathrm{CH}_{3} \mathrm{COOH}+$

\section{$0,25 \mathrm{CO} 2$}

2. $\mathrm{CH} 3 \mathrm{COOH} \rightarrow \mathrm{CH} 4+\mathrm{CH}_{2}$

3. Reaksi keseluruhannya

$\mathrm{CH}_{3} \mathrm{CH}_{2} \mathrm{COOH}+0,5 \mathrm{H}_{2} \mathrm{O}->1,25 \mathrm{CO}_{2}+$ $1,75 \mathrm{CH}_{4}$

Dan kedua reaksi diatas menunjukan bahwa hanya satu golongan bakteri metan yang dibuhkan untuk proses fermentasi bahan organik. Asam asetat dan asam propionat yang difermentasi terdiri dari dua golongan yang berbeda untuk bakteri metan. Bakteri yang bertanggung jawab untuk asam asetat secara relatif mengalami perubahan di $\mathrm{pH}$ dan temperatur serta mempunyai perkembangan yang jauh lebih tinggi bila dibandingkan dengan bakteri pada gas metana. Sebagai hasilnya gas metana biasanya diasumsikan untuk menjadi bahan pengendalian dalam proses anaerobik.

Berikut adalah gambar proses pembentukan gas metana $\left(\mathrm{CH}_{4}\right)$ secara anaerobik dari bahan organik seperti yang terlihat pada gambar 1.

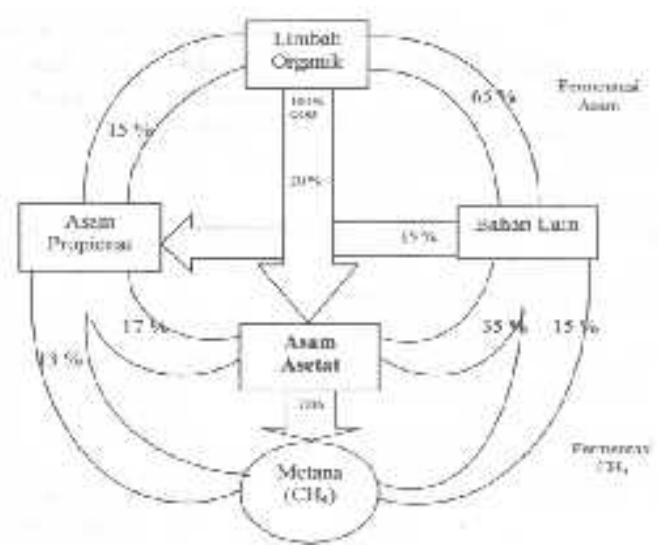

Gambar 1. Proses Fermentasi Bahan Organik

\section{Teknologi Pembuatan Biogas}

Sumber energi dari biogas ini sendiri yaitu tinja (manusia, sapi, kerbau, kuda, babi, dan ayam) ataupun bahan dari tumbuhan seperti dedaunan, ampas kelapa, sisa sayuran, atau dapat juga tumbuhan yang lain seperti enceng gondok. Pada bahan tinja, tidak perlu ditambahkan bahan bakteri pengurai sebab sudah cukup banyak mengandung bahan bakteri. Sedangkan apabila digunakan bahan dari tumbuhan, maka perlu dicampur dengan tinja sebagai pemicu dan mempercepat proses penguraian. Bahan tersebut dicampur dengan air. Supaya proses penguraian itu berjalan cepat, 
maka sampah organik itu dicacah terlebih dahulu. Proses penguraian berjalan optimal pada temperatur $35-37{ }^{\circ} \mathrm{C}$, dan kisaran derajat keasaman $(\mathrm{pH}) 6,8-7,8$ atau netral asam. Untuk menghilangkan bau gas dan untuk menaikkan mutu gas, maka biogas dicuci dengan jalan mengalirkannya melalui air yang dibubuhi sedikit kapur. Dengan pencucian ini bau gas yang tak enak menjadi hilang, dan gas $\mathrm{CO} 2$ yang tak berguna untuk bahan bakar terserap oleh air sehingga biogas yang diperoleh akhirnya dapat dibakar dengan hasil panas yang tinggi. Biogas kemudian dapat dialirkan ke rumah-rumah warga untuk memasak maupun kebutuhan yang lain.

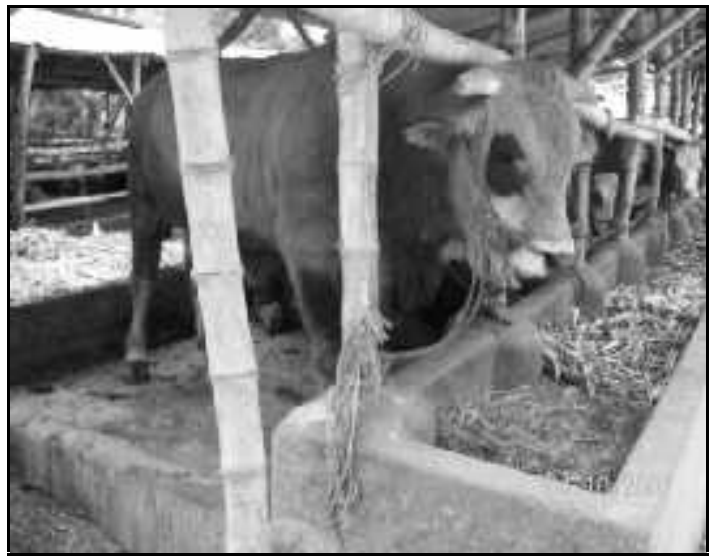

Gambar 2. Tinja sapi sebagai bahan biogas

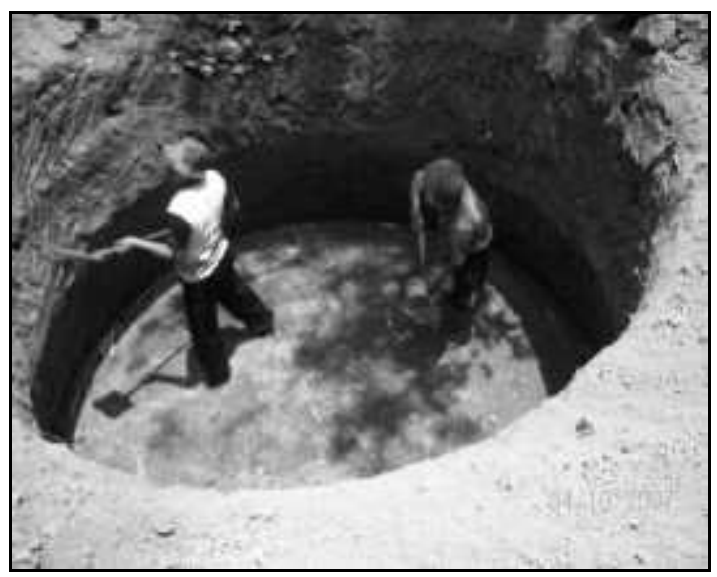

Gambar 3: pembuatan digester biogas

\section{Reaktor Skala Rumah Tangga}

Desain reaktor biogas skala rumah tangga yang digunakan dalam penelitian ini seperti pada gambar 4 berikut :

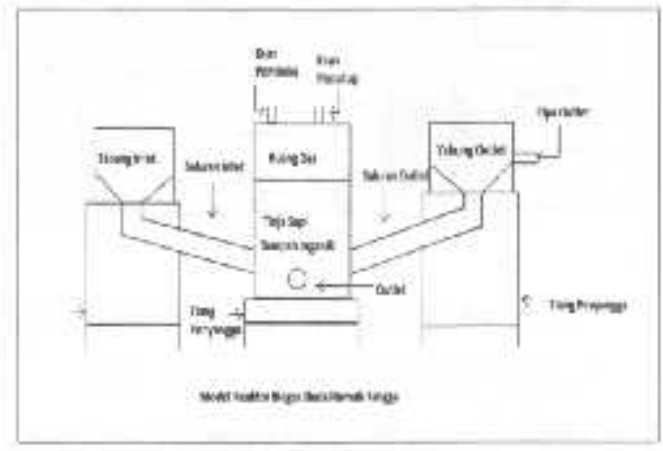

Gambar 4.Reaktor Biogas Skala Rumah Tangga

Reaktor biogas skala rumah tangga ini terbuat dari drum dimana terdapat 1 (sate) buah drum untuk pencema berisi tinja sapi sekaligus wadah gas yang tertampung dalam sebuah drum dan terdapat 2 (dua) bak untuk menampung tinja sapi dimana bak yang pertama sebagai inlet berisi tinja sapi baru untuk diproses menjadi biogas sedangkan bak kedua sebagai outlet berisi tinja sapi dari hasil akhir proses biogas.

Tinja sapi yang sudah tercampur secara homogen, dimasukan kedalam bak inlet untuk proses pembentukan biogas. Tinja sapi dari bak inlet tersebut akan masuk ke bak pencema gas secara otomatis melalui pipa inlet. Kemudian dibak pencerna tersebut tinja sapi akan membentuk gas baru yang disebut dengan biogas. Tinja sapi yang terdapat didalam bak pencerna selanjutnya akan mengalir ke bak outlet secara otomatis melalui pipa, outlet yang merupakan hasil akhir dari produksi biogas. Produk dari hasil akhir proses biogas ini selanjutnya dapat digunakan sebagai pupuk organik.

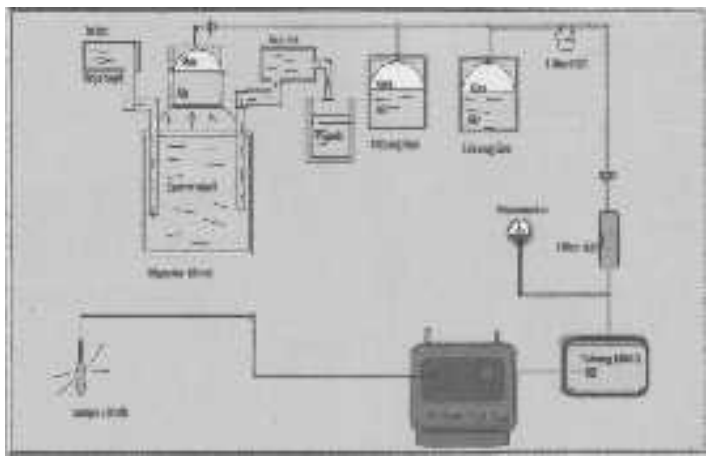

Gambar 5. Reaktor Biogas dan generator untuk Skala Rumah tangga.

Reaktor ini terdiri dari satu bagian Digester dan dua tabung gas yang di beri nama Gas Holder. Digester berfungsi 
sebagai fermentasi (Proses Mikro ogrnasime secara Anerobik) dan gas Holder sebagai Tempat Penampung gas. Filter $\mathrm{H}_{2} \mathrm{O}$ dan $\mathrm{H}_{2} \mathrm{~S}$ adalah sebagai penyaring $\operatorname{Air}\left(\mathrm{H}_{2} \mathrm{O}\right)$ dan Hidrogen Sulsur $\left(\mathrm{H}_{2} \mathrm{~S}\right)$, Memiliki manometer Untuk pengukur tekanan gas, Generator mengunakan bahan bakar gas sebagai pembangkit energi listrik.

\section{E. Rancangan Genset Mengunakan Energi Biogas}

Generator bekerja dengan prinsip induksi elektromagnetik terdiri dari : rotor dan stator. Stator merupakan elemen diam terdiri dari belitan-belitan jangkar sedangkan rotor merupakan elemen yang berputar terdiri dari belitan-belitan medan. Perbedaan penting antara generator DC dan generator AC yaitu : pada generator DC jangkar yang berputar dan medan sistem diam sedangkan generator AC sebaliknya.

Sistem instalasi Pembangkit Listrik Tenaga Biogas ( PLTBG) dapat di buat skema sebagai berikut :

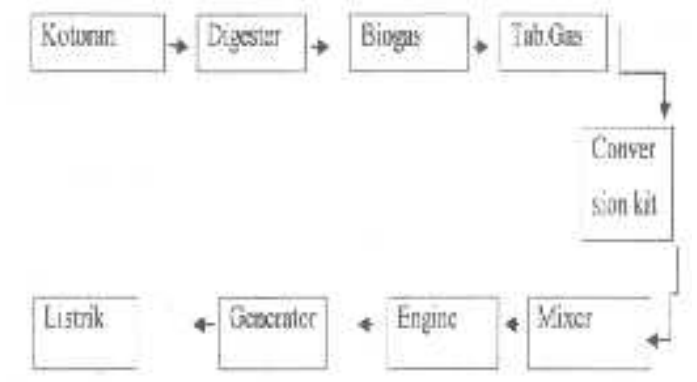

Gambar 6 Bagan Sistem instalasi pembangkit listrik dari Biogas kotoran sapi

Perubahan biogas menjadi energi listrik dilakukan dengan memasukan gas dalam tabung penampungan kemudian masuk ke konversion kit yang berfungsi menurunkan tekanan gas dari tabung sesuai dengan tekanan operasional mesin dan mengatur debit gas yang bercampur dengan udara didalam mixer, dari mixer bahan bakar bersama dengan udara masuk kedalam mesin dan terjadilah pembakaran yang akan menghasilkan daya untuk mengerakan generator yang menghasilkan energi listrik. Karakteristik pembakaran yang terjadi pada mesin diesel berbeda dengan pembakaran pada mesin bensin.

Bahan bakar Biogas membutuhkan rasio kompresi yang tinggi untuk proses pembakaran sebab Biogas mempunyai titik nyala yang tinggi 645 OC-750 OC dibandingkan titik nyala solar 220 OC, maka mesin disel umumnya digunakan secara duelfuel dengan rasio kompresi sekitar 15- 18. Proses pembakaran pada mesin duelfuel, bahan bakar biogas dan udara masuk ke ruang bakar pada saat langkah hisap dan kemudian dikompresikan didalam silinder seperti halnya udara dalam mesin disel biasa. Bahan bakar solar dimasukan lewat nozel pada saat mendekati akhir langkah kompresi,dekat titik coati atas (TNIA) sehingga terjadi pembakaran.

Temperatur awal kompresi tidak boleh lebih dari $80^{\circ} \mathrm{C}$ karena akan menyebabakan terjadinya knocking dan peristiwa knocking yang terjadi pada mesin duelfuel hampir sama dengan yang terjadi pada mesin bensin, yaitu terjadinya pembakaran yang lebih awal akibat tekanan yang tinggi dari mesin disel. Hal ini disebabkan karena bahan bakar biogas masuk bersama-sama dengan udara ke ruang bakar, sehingga yang dikompresikan tidak hanya udara tapi juga biogas. Perkiraan daya listrik yang dapat dihasilkan dari PLTBG adalah sebagai berikut

Tabel 3 Daya listrik yang dapat dihasilkan dari peternakan sedang dan besar.

\begin{tabular}{lcc}
\hline & Peternakan sedang & Peternakan besar \\
\hline Jumlah sapi ( Ekor) & 60 & 300 \\
Biogas yang dihasilkan ( m/ekor /hari ) & 0,94 & 0,94 \\
Biogas yang dihasilkan dari peternakan (m3/hari) & 70,5 & 282 \\
Daya yang dihasilkan (kW) & 3,05 & 15,27 \\
Energi yang dihasilkan $(\mathrm{kWh})$ & 73,2 & 366,5 \\
\hline
\end{tabular}

Pemilihan mesin pengerak generator PLTBG adalah mesin disel dan bensin. Di pasaran untuk mesin bensin harganya jauh lebih mahal dari mesin disel dengan daya yang sama. Dan untuk daya yang besar hanya mesin disel yang dapat digunakan sebab tidak adanya mesin bensin dengan daya besar dipasaran. Pengunaan kedua jenis mesin tersbut dalam kenyataannya menghasilkan efisiensi yang rendah 
sehingga perlu adanya modifikasi.

Modifikasi yang perlu dilakukan untuk mengubah mesin disel menjadi mesin yang berbahan bakar biogas adalah dengan cara menambahkan conversion kit dan mixer. Fungsi conversion kit adalah untuk mengatur debit dan menurunkan tekanan aliran bahan bakar sesuai dengan tekanan operasional yang diinginkan sedangkan mixer berfungsi sebagai pencampur bahan bakar dengan udara. Pemasangan mixer terletak pada saluaran masuk udara dan conversion kit terpasang antara mixer dan tabung gas ( Gas Holder ). Sistim modifikasi ini mengunakan sistim duelfuel yaitu mesin mengunakan dua bahan bakar yang dilakukan secara bersamaan dengan komposisi $70 \%$ bensin dan $30 \%$ biogas. Hal ini dilakukan karena titik nyala pembakaran biogas yang sangat tinggi yaitu sekitar $645^{\circ} \mathrm{C}-750^{\circ} \mathrm{C}$.

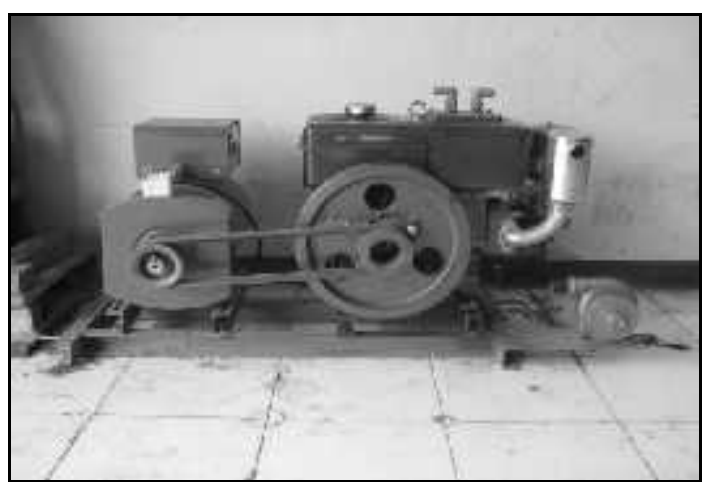

Gambar 7. Mesin Diesel kapasitas 7 PK untuk menghasilkan listrik daya 1.500 watt.

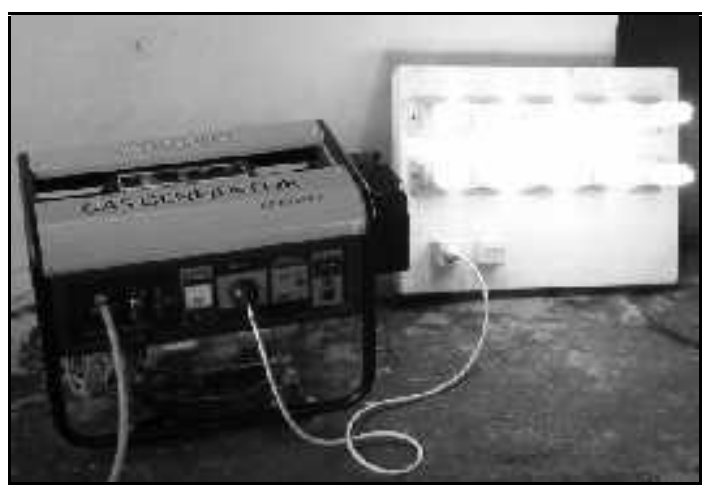

Gambar 8. Algen gas generator untuk 1500 watt.

$$
\text { Perhitungan }
$$

ekonomi pengunaan pembangkit listrik tenaga biogas (PLTBG) untuk peternakan sedang dan besar dengan pemakaian mesin disel dan bensin dan dibandingkan dengan keuntungan listrik yang dihasilkan yang disesuaikan dengan tarif dasar listrik PLN adalah sebagai berikut

Tabel 4. Perkiraan biaya investasi PLTBG pada Peternakan sedang dan besar

\begin{tabular}{|c|c|c|c|c|}
\hline & \multicolumn{2}{|c|}{ Peternakan sedang } & \multicolumn{2}{|c|}{ Peternakan besar } \\
\hline & Mesin bensin $(3 \mathrm{KW})$ & Mesin diesel ( $3 \mathrm{KW})$ & Mesin bensin & Mesin diesel $(15 \mathrm{KW})$ \\
\hline Harga mesin & $8.000 .000,00$ & $2.500 .000,00$ & Tidak ada & $51.500 .000,00$ \\
\hline Conversion kit + mixer & $8.000 .000,00$ & $2.500 .000,00$ & & $4.800 .000,00$ \\
\hline Total Investasi ( Rp) & $12.800 .000,00$ & $7.000 .000,00$ & & $56.300 .000,00$ \\
\hline
\end{tabular}

Tabel 5. Perkiraan biaya operasi PLTBG pada peternakan sedang dan besar

\begin{tabular}{lcccc}
\hline & \multicolumn{2}{c}{ Peternakan sedang } & \multicolumn{2}{c}{ Peternakan besar } \\
& $\begin{array}{c}\text { Mesin bensin } \\
(3 \mathrm{KW})\end{array}$ & $\begin{array}{c}\text { Mesin diesel } \\
(3 \mathrm{KW})\end{array}$ & $\begin{array}{c}\text { Mesin bensin } \\
\text { Mesin diesel } \\
(15 \mathrm{KW})\end{array}$ \\
\hline $\begin{array}{l}\text { Harga bahan bakar selain } \\
\text { biogas/tahun }\end{array}$ & Tidak ada & $2.891 .000,00$ & Tidak ada & $13.008 .600,00$ \\
$\begin{array}{l}\text { Perawatan rutin/tahun } \\
\text { (0,05 x harga mesin) }\end{array}$ & $400.000,00$ & $125.000,00$ & & $2.575 .000,00$ \\
$\begin{array}{l}\text { Biaya operator mesin / tahun } \\
\text { Total operasi ( Rp) }\end{array}$ & $7.300 .000,00$ & $7.300 .000,00$ & & $7.300 .000,00$ \\
\hline
\end{tabular}

Biaya investasi dari mesin diesel lebih kecil dari pada mesin bensin, sehingga mesin diesel lebih menguntungkan dari segi ekonomi. Di lain sisi dari aspek perawatan mesin diesel dan mesin bensin dapat dikatakan sebanding dan 
membutuhkan biaya yang relatif sama. Dilihat dari aspek operasi mesin diesel lebih mudah, mempunyai umur operasi yang lama dan mengunakan sedikit bahan bakar untuk penyediaan daya yang sama dibandingkan dengan mesin bensin. Hal ini dapat dijadikan alasan bahwa mesin disel lebih menguntungkan sebagai mesin pengerak pada PLTBG.

Keuntungan dari membangkitkan listrik dari PLTBG adalah energi listrik yang dapat dihasil dikalikan dengan harga listrik yang harus dibayar pemakai jika mengunakan listrik dari PLN. Harga listrik Rp. 545/kWh dan biaya beban Rp. 30.000/kVA. Nilai rupiah yang dapat dihasilkan dari membangkitkan listrik dari biogas pada peternakan sedang dengan daya $3 \mathrm{~kW}$ ( 4 kVA ) dalam satu tahun dengan pengunaan tiap hari 24 jam adalah Rp. 15.762.600,00-

Analisa ekonomi pembangkit listrik tenaga biogas dengan mesin pengerak dari mesin diesel untuk peternakan skala, sedang, Jika bunga investasi untuk kredit dari bank $19 \%$ adalah :

Total investasi

$=$ Rp. $7.300 .000,+$ Rp. $7.300 .000, x 19 \%$

$=$ Rp. 8.687.000,00

Umur teknis ekonomi 10 Tahun

Depresiasi

$=$ Rp. $8.687 .000,00 / 10$

$=$ Rp. $868 \cdot 700,00$

Cash flow

$=$ Keuntungan + Depresiasi - biaya operasional

$=$ Rp. $15 \cdot 762 \cdot 600,00+868 \cdot 700,00-$

Rp. $10.316 .000,00=$ Rp. $6220.400,00$

IRR. ( Initial Rate of Return)

$=72 \%$

NPV ( Net Present Value )

$=$ Rp. $15.726 .618,00$

BCR ( Benefit Cost Ratio) $=1,45$

PB ( Pay back $)=1$ tahun 5 bulan

Nilai rupiah yang dapat di hasilkan sesuai harga listrik dari PLN membangkitkan listrik dengan biogas pada peternakan besar dengan daya $15 \mathrm{~kW} 19 \mathrm{~W}$ dalam satu tahun dengan pengunaan tiap hari 24 jam adalah : Rp. 78.453.000,00. Jika bunga investasi untuk kredit dari bank $19 \%$ maka analisa pembangkit listrik tenaga biogas untuk peternakan Skala besar adalah Total investasi

$=$ Rp. $56.300 .000,+$ Rp. $56.300 .000 \times 19 \%$ $=$ Rp. 66.997.000,00.

Untuk teknis ekonomis 10 Tahun Depresiasi
$=$ Rp. 66.997.000,00/10

= Rp. 6.997.000,00

Cash Flow

$=$ Rp. Keuntungan + Depresiasi

- biaya operasional

$=$ Rp. $78 \cdot 345 \cdot 000,00+$ Rp.

6.699.700,00-

Rp. $22.883 .600,00=$ Rp.

$61.537 .200,00$

IRR ( Initial Rate of Return) $=93 \%$

NPV ( Net Present Value $)=$ Rp.

170.743.335,00

BCR ( Benfit Cost Ratio) $=2,87$

PB $($ Pay Back $)=1$ Tahun 1 bulan

Berdasarkan hasil perhitungan

diatas dapat diambil kesimpulan untuk skala peternakan sedang dan besar lebih baik mengunakan mesin disel, disamping ekonomis aspek operasi mesin diesel mudah dibandingkan dengan mesin bensin. Umur operasi mesin diesel mempunyai jangka waktu yang lama.

Kendala yang dihadapi untuk pembangaunan PLTBG adalah modal awal yang besar, kurang penguasaan ilmu tentang pembangunan PLTBG , adanya keraguan dari pemilik peternakan tentang berhasil tidaknya PLTBG, kurangnya perhatian pemerintah tentang penelitian PLTBG dan kurangnya pemberian bantuan dana bagi pemilik petemakan. Saran untuk mengatasi masalah diatas adalah peminjaman modal ke bank atau pemberian kredit lunak untuk oleh pemerintah kepada pemilik peternakan, perlunya mempelajari lebih dalam modifikasi yang perlu dilakukan pada mesin untuk PLTBG, pemberian kucuran dana untuk penelitian dari pemerintah, perlu adanya penyuluhan terhadap peternakan sapi sehingga tidak adanya keraguan lagi dari para peternak untuk pembangunan PLTBG.

\section{METODE PENELITIAN \\ Metode Pengumpulan Data}

Metode pengumpulan data yang dipakai dalam penelitian ini adalah dengan melakukan, penelitian di laboratorium Teknik Elektro Universitas PGRI Adi Buana Surabaya. Dalam penelitian ini jenis data yang diperlukan merupakan data yang diperoleh dari hasil pengamatan yang dilakukan secara langsung di lapangan, yaitu data mengenai tekanan gas yang diperoleh dan waktu yang dibutuhkan sampai dengan menghasilkan gas yang optimal. 


\section{ANALISIS DATA}

\section{Penyajian hasil Penelitian}

Data yang sudah berhasil dikumpulkan melalui kegiatan eksperimen pada penelitian ini adalah data mengenai tekanan gas dan lama produksi gas yang dihasilkan untuk tiap kategori yang berbeda-beda. Data yang dihasilkan diperoleh dari hasil pengamatan dilapangan secara langsung.

Penelitian ini dilakukan di laboratorim Teknik Elektro guna memperoleh data tentang tekanan gas dan lama produksi gas yang dihasilkan untuk tiap kategori yang

berbeda-beda.

Tabel 6. Data Percobaan Biogas Campuran Tinja Sapi + Air

\begin{tabular}{|c|c|c|c|}
\hline Pengamatan & Tinja + Air (50\%:50\%) & Waktu & Tekanan/KpA \\
\hline 1 & 140 liter & 24 jam & 0 \\
\hline 2 & 140 liter & $48 \mathrm{jam}$ & 1 \\
\hline 3 & 140 liter & 72 jam & 1,5 \\
\hline 4 & 140 liter & $96 \mathrm{jam}$ & 2.2 \\
\hline 5 & 140 liter & 120 jam & 2.4 \\
\hline 6 & 140 liter & 144 jam & 2.7 \\
\hline 7 & 140 liter & 168 jam & 2.7 \\
\hline \multicolumn{4}{|c|}{ Tabel 7. Percobaan Tinja Sapi + Air + Sampah Organik } \\
\hline Pegamatan & $\begin{array}{c}\text { Tinja + Air + Sampah organik } \\
30 \%: 30 \%: 40 \%\end{array}$ & Waktu & Tekanan /KpA \\
\hline 1 & 140 liter & 24 jam & 0 \\
\hline 2 & 140 liter & 48 jam & 0 \\
\hline 3 & 140 liter & $72 \mathrm{jam}$ & 0 \\
\hline 4 & 140 liter & 96 jam & 0,5 \\
\hline 5 & 140 liter & 120 jam & 1 \\
\hline 6 & 140 liter & 144 jam & 1.4 \\
\hline 7 & 140 liter & 168 jam & 1.9 \\
\hline 8 & 140 liter & 92 jam & 2.0 \\
\hline 9 & 140 liter & 216 jam & 2.0 \\
\hline 10 & 140 liter & 240 jam & 2.3 \\
\hline 11 & 140 liter & 264 jam & 2.3 \\
\hline 12 & 140 liter & 288 jam & 2,4 \\
\hline 13 & 140 liter & 312 jam & 2,5 \\
\hline${ }^{1} 14$ & 140 liter & 336 jam & 2.5 \\
\hline
\end{tabular}

Data Pada tabel 6. dan tabel 7. bertujuan untuk mengetahui efektifitas campuran pengolahan dan pemanfaatan Limbah peternakan Sapi dan Sampah Oraganik dari Domestik ( Sampah Rumah Tangga ). Pada kategori perbandingan campuran untuk pegolahan Tinja Sapi $30 \%$ : $30 \%$ Sampah Organik : $40 \%$ Air memiliki tekanan Gas Lebih rendah dibandingkan dengan Kategori Tinja sapi morn : air lebih tertinggi yaitu sebesar 2,7 Kpa. Dan proses pengolahan secara anaerobik ( tanpa udara ) pada kategori perbandingan campuran tinja sapi murni dan air lebih cepat dibandingkan dengan kategori campuran Sampah organik : Air Tinja sapi.
Data mengenai keefisienan pengunaan bahan bakar untuk generator 1000 watt selama waktu operasional yaitu perbandingan antara bahan bakar bensin Murni : Biogas Murni dan BBMG , tekanan gas yang optimal untuk tiap kategori yang berbeda - beda. Data yang dihasilkan diperoleh dari hasil pengamatan dilapangan secara langsung. Penelitian ini dilakukan di Desa Kintelan Kecamatan Puri Kabupaten Mojokerto dan laboratorium Teknik Elektro guna memperolehd ata Keefisienan pembakaran dan penghematan bahan bakar, tekanan gas dan lama pengunaannya selama operasinal yang dihasilkan untuk tiap kategori yang berbedabeda 
Tabel 8. Hasil percobaan waktu operasional generator 1000 watt dengan BBM ,BBG, dan BBMG

\begin{tabular}{cccccc}
\hline No & Percobaan & Bensin/liter & Biogas/KpA & Waktu (Menit) & Daya \\
\hline 1 & 1 & 1 liter & 0 & 83 & 1000 watt \\
& 2 & 1 liter & 0 & 86 & 1000 watt \\
& 3 & 1 liter & 0 & 88 & 1000 watt \\
2 & 4 & 1 liter & 0.9 & 97 & 1000 watt \\
& 5 & 1 liter & 9.9 & 100 & 1000 watt \\
& 6 & 1 liter & 0.9 & 124 & 1000 watt \\
3 & 7 & & 4 & 0 & Tidak ada energi listrik \\
& 8 & & 4 & 0 & Tidak ada energi listrik \\
& 9 & & 4 & 0 & Tidak ada energi listrik \\
\hline
\end{tabular}

Data yang sudah berhasil dikumpulkan melalui kegiatan eksperimen pada penelitian ini adalah data mengenai pemumian biogas yang dihasilkan untuk tiap kategori yang berbeda - beda. Data yang dihasilkan diperoleh dari hasil pengamatan dilapangan secara langsung. Penelitian ini dilikukan di desa Kintelang kecamatan Puri Kabupaten Mojokerto guna memperoleh data pengunaan filtrasi Biogas yang keefisienan untuk pemurnian biogas untuk pengunaan pada mesin generator dan kompor gas dan pengawetan pada mesin.

Tabel 9. Efisiensi filtrasi bioga variable bebas

\begin{tabular}{ccccc}
\hline No & Perbandingan filtrasi & Efisiensi filtrasi & $\begin{array}{c}\text { Tekanan gas } \\
(\mathrm{KpA})\end{array}$ & $\begin{array}{c}\text { Pembakaran pada } \\
\text { mesin/kompor gas }\end{array}$ \\
\hline 1 & Instalasi tanpa filtrasi & $\begin{array}{c}\text { Gas campuran } \\
\text { air dan sulfur }\end{array}$ & 4 & Kurang baik \\
2 & Filtrasi tanpa air kapur & Gas mumi & 4 & Baik \\
3 & $\begin{array}{c}\text { Filtrasi + Air Kapur + } \\
\text { Sulfurizer ( H2s ) }\end{array}$ & Gas Murni & 4 & Lebih baik \\
\hline
\end{tabular}

Data yang di sajikan merupakan data gabungan untuk semua variasi Filtrasi yaitu Variasi (I): Biogas tanpa Filtrasi (II) : Biogas dengan filtrasi tanpa air kapur $\mathrm{H}$ (III): Biogas dengan Filtrasi + air kapur. Data yang di sajikan adalah data tentang tiap-tiap variasi filtrasi dimana data yang disajikan keefisienan dalam pemurnian biogas untuk mengurangi kandungan gas $\mathrm{CO}_{2}, \mathrm{H}_{2} \mathrm{O}$, $\mathrm{H}_{2} \mathrm{~S}$ dan bau yang terkandung dalam biogas yang diamati dengan proses pembakaran pada mesin dan kompor gas selama waktu operasional. Secara keseluruhan dari pengamatan untuk ketiga variasi. Didapatkan bahwa biogas dengan filtrasi + air kapur merupakan variasi filtrasi yang sangat efektif dan efisien untuk pemurnian biogas.

\section{KESIMPULAN DAN SARAN}

\section{A. Kesimpulan}

Berdasarkan hasil penelitian yang telah dilakukan, didapatkan tekanan gas dan waktu yang dibutuhkan sampai dengan menghasilkan gas yang maksimal. Dan pernyataan diatas dapat ditarik kesimpulan bahwa :

1. Tekanan gas dan waktu yang dibutuhkan sampai dengan menghasilkan gas yang maksimal terjadi pada variasi campuran tinja sapi moan : Air sebesar 2,7 KpA dalam waktu 4-7 hari atau $4 \times 24$ jam = $7 \times 24$ jam.

2. Tekanan gas yang dihasilkan digester dengan perbandingan campuran pada kategori yang berbeda - beda, menghasilkan tekanan gas yang berbeda - beda pula.

3. Pengolahan limbah peternakan sapi sangat bermanfaat secara ekonomis menghasilkan biogas sebagai bahan bakar dan komposting menjadi pupuk organik untuk pertanian.Bila kelebihan masyarakat bisa menjual sebagai pendapatan ekonomi sehari-hari.

4. Mesin duelfuel 1000 watt yang dirancang lebih efektif untuk 


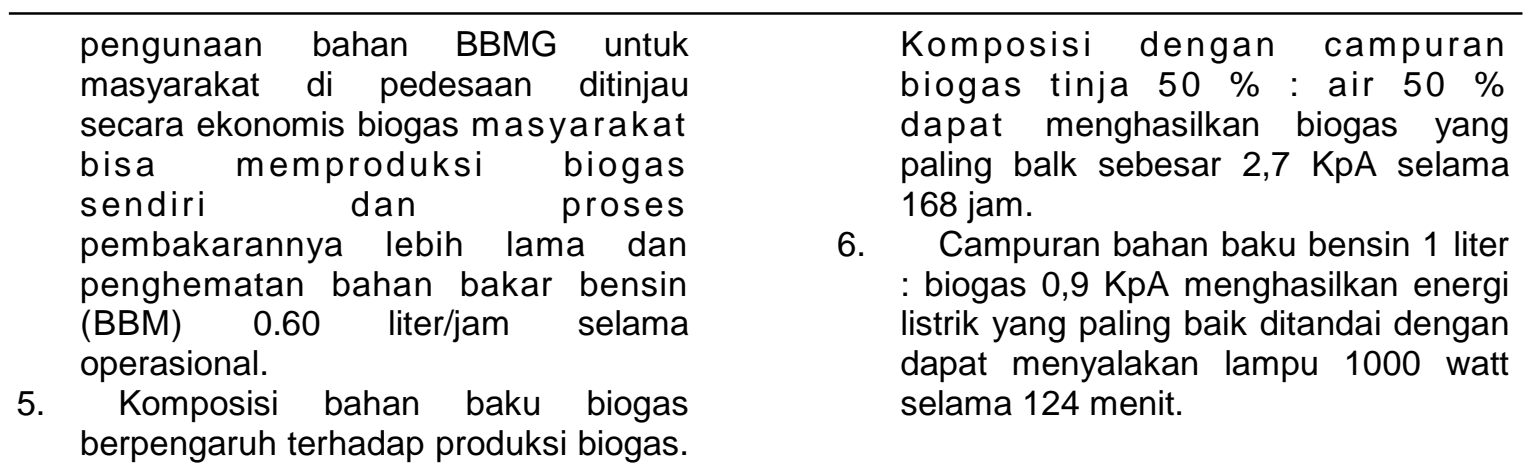

\section{DAFTAR PUSTAKA}

Anonymus ,International Symposium and Industrialization Forum on Biogas Chengdu 2008

Anonymus , JDC GREEN ENERGY POWER

Anonymus, WaZer Pembangkit Listrik Tenaga Sampah Ala Mahasiswa ITS Alkholif Muhammad, Skripsi FTSP -UNIPA 2009

Budi Prijo Sembodo, Setyo purwoto, Rusdianto Rancangan Bangung Genset mengunakan energy biogas (Fak. Tek. Industri Unipa 2009)

Balai Pengkajian Teknologi Pertanian Kaltim ,Pemanfatan Limbah ternak sapi menghasilkan Biogas , Pupuk dan Pakan

Direktorat Jendral Pertanian, Teknologi Bioenergi 2006.

Jianan ,Mr , Puxin Sience Tecnology-Chenze 2008

Kadin Abdul, Energi, Sumber daya, Inovasi, Tenaga Listrik dan Potensi Ekonomi Larry D. Benefield, Biological Process Design fbr wastewater treatment

Aburun University Clifford W.Randell Virgin Polytechnik and State Universiy (hal. 259)

www: Unsa ac. id. Sejarah Teknologi Biogas 